\title{
Analitik Hiyerarşi Prosesi Yöntemi ile Lojistik Sektöründeki İdeal Satış Personeli Profiline Ulaşmak: Uluslararası Bir Lojistik Firma Örneğ $i^{1}$
}

\author{
Özgür KABADURMUŞ² ve Duygu DEMİRELÖZ ${ }^{3}$
}

$\ddot{O}_{z}$

Uluslararası lojistik sektöründe yoğun bir rekabetin yaşanması, ulusal ve uluslararası faaliyet gösteren lojistik şirketlerini insan kaynaklarını optimal şekilde yönetme stratejisine yönlendirmektedir. Bu bağlamda, lojistik şirketlerinde nakit akış döngüsünde önemli rollere sahip olan satış personellerinin yetkinliklerinin belirlenmesi, şirketlerdeki başarıyı sürdürülebilir hale getirebilmek adına büyük önem taşımaktadır. Bu çalısmanın amacı insan kaynağının optimal yönetim stratejisinin başarılı bir şekilde uygulanması kapsamında lojistik şirketlerindeki satış personelinin yetkinliklerinin belirlenmesi ve işe alımda kullanılmasıdır. Çalışmada önerilen modeli test etmek üzere vaka çalışması olarak ulusal ve uluslararası alanlarda faaliyet gösteren bir şirketin lojistik operasyonlarında çalışacak satış personelinin yetkinlikleri belirlendikten sonra çok kriterli karar verme yöntemi olan Analitik Hiyerarşi Prosesi uygulanarak şirket için en uygun aday seçilmiş ve sonuçlar tartışılmıştır.

Anabtar Kelimeler: Lojistik yönetimi, Analitik hiyerarşi prosesi, İnsan kaynakları yönetimi

\section{Determining the Profile of Ideal Sales Personnel by Applying Analytical Hierarchy} Process: Case of an International Logistics Company

\begin{abstract}
The intense competition in the logistics industry forces logistics companies that operate locally or globally to strategically manage their human resources in a better way. In this context, determining the competencies of sales personnel who have significant roles in the cash flow cycle in logistics companies is crucial in order to make success in the companies sustainable. The purpose of this study is to determine the competencies of sales personnel in logistics companies in the context of the successful implementation of the optimal strategy for human resource management. To test our proposed model, the competencies of the sales personnel to work in the logistics operations of a company operates nationally and internationally are examined as a case study. Then the most suitable candidate for the company is selected by applying the Analytical Hierarchy Process and the results are discussed.
\end{abstract}

Key Words: Logistics Management, Analytical hierarchy process, Human resources management

\section{Atıf İçin / Please Cite As:}

Kabadurmuş, Ö. ve Demirelöz, D. (2020). Analitik hiyerarşi prosesi yöntemi ile lojistik sektöründeki ideal satış personeli profiline ulaşmak: uluslararası bir lojistik firma örneği. Manas Sosyal Araștırmalar Dergisi, 9(3), 17881802.

Geliş Tarihi / Received Date: 03.05.2019

Kabul Tarihi / Accepted Date: 27.05.2020

\footnotetext{
${ }^{1}$ Bu çalışma, Duygu Demirelöz’ün "Çok kriterli karar verme yöntemlerini kullanarak lojistik sektöründeki ideal satış personeli profiline ulaşmak: Uluslararası bir firma örneği” başlıklı yüksek lisans tezinden (Danışman: Dr. Öğr. Üyesi Özgür Kabadurmuş) üretilmiştir.

2 Dr. Öğr. Üyesi - Yaşar Üniversitesi, ozgur.kabadurmus@yasar.edu.tr - ORCID: 0000-0002-1974-7134

3 İnsan Kaynakları Uzman1 - Arkas Lojistik, duygu.demir@arkas.com.tr - ORCID: 0000-0002-9092-3380
} 


\section{Giriş}

Teknolojideki gelişmeler ve tüketicilerin artan beklentileri yoğun rekabet ortamını beraberinde getirmektedir. Şirketler rekabet avantajı elde edebilmek ve pazardaki paylarını koruyabilmek adına insan kaynağından maksimum verimi almayı amaçlamaktadır (Boudreau ve Ramstad, 2003). Personel seçimi bir şirket için kritik bir iştir ve bu özellikle şirket genelinde stratejik değişimler olduğu dönemlerde daha da önemli hale gelir (Kelemenis ve Askounis, 2010). Bu nedenle, personel seçim sürecinin etkili bir şekilde tasarlanması ve yürütülmesi gereklidir ve açık bir pozisyona doğru bir kişinin alınması ancak bu şekilde gerçekleştirilebilir (Lin, 2010). Global rekabetin hızla arttığ1 lojistik sektöründe de personel seçimi çok önemlidir ve bu çalışmada ülkemizde de ekonomik açıdan kritik öneme sahip olan lojistik sektöründe personel seçimi problemi ele alınmıştır.

Lojistik sektörü, gelişimini sürdüren sektörlerden biridir. Dünya Bankası'nın Dünya genelinde 150 ülkeyi karşılaştırarak hazırladığ1 Lojistik Performans Endeksi raporuna göre 2018 ylında lojistik sektörü global olarak 4,3 trilyon dolarlık bir hacme ulaşmıştır (Arvis vd., 2018). Türkiye bu listede lojistik performansi açısından 2014 yilında 30. sırada yer almaktayken, 2016 yilinda 34. ve 2018 yilinda 37. sıralara gerilemiştir. Bu durum da artan global rekabeti ve lojistik hizmetlerindeki performansın önemini ortaya koymaktadır. Bu bağlamda, istihdam edilen personelin kişisel donanımı, yetkinlikleri ve çalısılacak pozisyonun gerektirdiği bilgi birikimine sahip olması müşterilerin lojistik hizmet sağlayıcısı ve tedarikçi seçiminde belirleyici kriterlerden biri haline gelmiştir. Örneğin, Kahraman vd. (2003)'ün çalışmasında müşteriyle iletişimi açık tutmanın ve sürekli bilgilendirmenin yanı sıra çalışanların profesyonelliği, bilgisi ve davranışları gibi özelliklerin tedarikçi firmaların seçiminde önemli rol oynadığ1 ortaya konmuştur. $\mathrm{Bu}$ nedenle işe giriş sürecinde adayların değerlendirilmesi ve pozisyon için en uygun adayın seçilmesi noktasında şirketlerdeki insan kaynakları yönetimi uygulamaları kritik öneme sahiptir.

Bu çalışmada lojistik firmalarında "en iyi ve en doğru adayı" tespit edebilmek amacıyla Analitik Hiyerarşi Prosesi (AHP) kullanılmıştır. Çok kriterli karar verme yöntemlerinden biri olan AHP yöntemi, bu çalışmada önerdiğimiz personel seçimi modelinde belirli bir pozisyon için sahip olunması gereken yetkinlikler ve bu yetkinliklerin alt kriterlerinin ağırlıklandırılması ile doğru adayı tespit etmek için kullanılmıştır. Bu çalışmada özellikle lojistik sektöründe faaliyet gösteren şirketlerde görev alacak satış temsilcisi pozisyonunun yetkinlikleri belirlenmiştir. Bu çalışma, bu anlamda lojistik sektöründe satış personeli seçimi konusunda çok kriterli bir karar verme yöntemi önererek bu konuda literatürdeki bir açığ1 da kapatmaktadır. Çalışmamızın en önemli katkılarından biri de gerçek bir örnek vaka aracılığı ile lojistik sektöründeki satış personeli seçiminde gerekli olan yetkinliklerin ve kriterlerin ortaya çıkarılmasıdır. $\mathrm{Bu}$ yetkinlikler önce ana kriterler ve ardından da alt kriterler şeklinde sınıflandırılmış ve sonrasında AHP yöntemi ile önem ağırlıklarına göre sıralandıktan sonra şirket için ideal satış personeli profili ortaya çıkarılmıştır. Önerilen yöntemin son aşamasında ise, yine AHP yöntemi ile satış pozisyonu için en uygun aday seçilmektedir.

Bu kapsamda önerilen modeli test etmek üzere gerçek bir vaka çalısması olarak Türkiye'de alanında lider bir lojistik şirketinin lojistik operasyonlarında çalışacak olan satıs personeli için gerekli yetkinlikler oluşturulmuş ve ardından da işe başvuran adaylar kıyaslanmıştır. İncelenen gerçek vaka analizinde, yöntemin farklı pozisyonlar için nasıl uygulanacağını göstermek ve aynı şirkette farklı satış pozisyonları için gerekli yetkinliklerin nasıl değiştiğini gözlemlemek için deniz yolu ve kara yolu satış personeli olarak iki farklı işe alım süreci gerçek veriler kullanılarak incelenmiş ve çıkan sonuçlar karşılaştırılmıştır. Ana ve alt kriterlerin ağırlıklandırılması, şirkette çalışmakta olan karar vericiler tarafindan belirlenmiştir. Bu bağlamda AHP yöntemi ile elde edilen veriler sonucunda şirket stratejik hedeflerine ve pozisyona en uygun aday1 şirket disiplinine uygun olarak seçmiş olmaktadır. Bu da geliştirilmiş olan modelin gerçek hayatta uygulanabilirliğini ve ileride lojistik sektörüne kolay entegre edilmesini sağlayabilecek bir unsur olarak katkısını ortaya koymaktadır.

Bu çalışmanın 2. Bölümü'nde lojistik sektöründe insan kaynakları, işe alım süreçleri ve çok kriterli karar verme yöntemlerinin bu alanlarda kullanılması üzerine bir literatür taraması sunulmuştur. Kullanılan yöntem olan AHP yöntemi 3. Bölüm'de anlatılmıştır. Yöntemin test edildiği vaka çalışmaları 4. Bölüm'de sunulmuş ve sonuçlar verilmiştir. 5. Bölüm'de ise çalışmanın değerlendirmesi ve gelecek çalışmalar özetlenmiştir. 


\section{Literatür Taraması}

İnsan kaynakları yönetimi (IKKY) bir şirket içindeki kişilerin yönetimini ifade etmektedir. Şirketin amaçlarını gerçekleştirmek için çalışanların uygun sayı ve beceri karışımını elde etmek, geliştirmek, kullanmak, değerlendirmek, sürdürmek ve muhafaza etmekle görevli faaliyetler, politikalar ve uygulamaları kapsamaktadır. İKY'nin amac1, aynı anda bireysel hedeflere ve toplumsal hedeflere (yasal uygunluk ve sosyal sorumluluk) erişmek amacıyla yüksek üretkenlik ve maksimum verimliliği elde etmek için çalışanların katkılarını maksimize etmektir (Dessler, 2012). İKY, aynı zamanda, şirketin insan kaynakları stratejik hedeflerine ulaşma doğrultusunda çalışanların memnuniyetini sağlamak için analiz etme ve yönetme süreci olarak da ifade edilmektedir (Hellriegel vd., 2008).

Rekabetçi bir insan kaynağı organizasyonel başarıyı beraberinde getirmektedir. Etkin ve verimli bir insan kaynağı, iş memnuniyetsizliği ve devamsızlık gibi insan kaynakları ile ilgili sorunları en aza indirirken, üretken ve iş bilinci yüksek çalışma grupları oluşturacaktır (Chyn ve Kaliannan, 2011). Şrketler, İKY’ndeki başarılı politikalarının ve uygulamalarının, verimlilik, kalite ve mali performans gibi farklı alanlardaki performansı artırabileceğinin farkına varmışlardır. Bu noktada, şirketler için dengeleyici ve performans arttırıcı unsur olan İKY, stratejik bir değer kazanmıştır.

Ülke ekonomisine olan katkısından dolayı hizmet sektörlerinde yaratılan istihdam diğer sektörlere kıyasla artış göstermektedir. Bu noktada lojistik sektörü kapsamlı ve karmaşık yapısı dolayısıyla çok daha fazla işgücüne ihtiyaç duymakta olup en çok istihdam yaratan hizmet sektörlerinden biri haline gelmektedir (Koban ve Keser, 2013).

Literatürde, çeşitli sektörlerde konumlanan firmaların piyasadaki performansını arttırmaya yönelik yapılan insan kaynakları çalışmalanı veya satış personellerinin firmalar üzerindeki etkileri araştırılmış olmasına karşın (Periatt vd., 2007; Chen vd., 2014; İbicioğlu ve Ünal, 2014; Candemir vd., 2015) lojistik sektöründeki uygulamalar az sayıdadır (Akar ve Çakır, 2016; Çaylan ve Yıldız, 2016; Ilgaz, 2018; Korkmaz, 2019). Bu çalışma ise literatürde yer alan diğer lojistik sektöründeki insan kaynakları üzerine olan çalışmalardan farklı olarak satış alanına odaklanmıs olması ve ideal bir satış personeli profilinin nasıl olması gerektiğini araştırarak işe alım sürecinde personel yetkinliklerinin sürece olan etkisini incelemesi ile ayrilmaktadır.

Periatt vd. (2007) dışa dönüklük, tecrübeye açıklık, hoşgörü ve vicdanlılık gibi kalıcı özelliklerin müşteri yönelimi arasındaki ilişkiyi ölçmüştür. Çalışmalarında seçim aracı olarak "büyük beşli" kişilik faktörüne odaklanmaktadırlar. Çalışmanın amacı, büyük beşli kişilik faktörlerinin lojistik çalışanlarının müşteri yönelimlerini ne derece öngördügünü araştırmaktır. Satış personelinin kişisel yetkinlikleri ve satış performansı arasındaki ilişkiyi temel alan çalışmada ise Candemir vd. (2015) perakende sektöründe çalışan satış elemanlarının kişisel niteliklerinin ve aldıkları satış eğitimlerinin satış performansları üzerindeki etkisini ölçmektedirler. İzmir ilinde perakende sektöründe faaliyet gösteren işletmelerde çalışan satış personelinin ele alındığ çalışmada 473 anket değerlendirilmeye alınmıştır. Anket sonucunda elde edilen bulgularla, satış elemanının satış öncesi hazırlık yapması ve yaklaşımının satış sürecini hızlandırma anlamında bir katkısının olmadığı; işe başlama öncesinde satışa yönelik eğitim alması ve satış çalışmaları boyunca düzenli olarak eğitimler almaya devam etmesinin de satış sürecini dolaylı olarak olumlu yönde etkilediği kanısına varılmıştır. Bu kapsamda, işletmelerin bünyelerinde çalışan satış elemanlarının kişisel özelliklerine daha fazla odaklandığ1 ve özelliklerini verilen eğitimlerle satış süreçlerine göre şekillendirmeyi mümkün hale getirdikleri takdirde doğrudan satış elemanlarının dolaylı olarak da işyeri performansını daha fazla arttırabileceği görüşüne varılmıştır.

AHP yöntemiyle personel seçimi temelli bir çalışmada ise Chen vd. (2014), AHP’ye dayalı İKY seçimine odaklanmaktadırlar. İKY'nin işlevleri temel iş, rutin iş ve stratejik iş olarak tanımlanmakta olan çalışmada bu işlevleri kapsayan, IKKY problemi için üç seviyeli bir endeks sistemi oluşturulmaktadır. Temel iş kapsamında alt kriterler terfi ve pozisyon yönetimi, yönetim kararları ve yönetim bilgi sistemleri olarak belirlenmiştir. Rutin iş kapsamında alt kriterler işe alım, performans yönetimi, eğitim ve gelişim, ücret, refah ve çalışan ilişkileri olarak belirlenmiştir. Stratejik iş kapsamında ise stratejik insan kaynakları yönetimi, kurum kültürü, organizasyonel değişimler ve finansal girdiler olarak belirlenmiştir. Çalışmanın sonucunda önerilen yöntem performansının gerçeğe oldukça yakın olduğunu ve önerilen sorundaki en önemli faktörlerin "yönetim kurallarr", "maaş ve refah" ve "kurum kültürü" olduğunu göstermektedir.

AHP ve personel seçimi temelli çalışmalarında İbicioğlu ve Ünal (2014) insan kaynakları yöneticisi seçiminde kullanılmak üzere bir model geliştirmişlerdir. Çalışmada AHP yöntemine 7 ana kriter ve 46 alt 
kriter dahil edilmiştir. Kriter ve alt kriter sayısının fazla olması nedeniyle bizim çalışmamızdan farklı olarak AHP'nin karşlaştırma yöntemi yerine puanlama yöntemi tercih edilmiştir. Her kriter ve alt kriterler ağırlıklandırllırken anketler aracılığı ile alınan uzman görüşleri değerlendirilmiştir. Önceki çalışmalara benzer olarak Akar ve Çakır (2016) çalısmalarında lojistik sektöründe faaliyet gösteren bir şirket için belirlenen ölçütlere en uygun adayların seçilmesine ilişkin çok kriterli karar verme problemine çözüm sunmayı amaçlamışlardır. Çalışmada lojistik personel seçimine ilişkin değerlendirme bulanık AHP ve MOORA yöntemleri kullanılarak yapılmıştır. Bulanık AHP adayın sahip olması beklenen niteliklerin önem dereceleri hesaplanmasında; MOORA yöntemi ise her adayın sahip olduğu kriter puanlarının bulanık AHP ile belirlenen ölçüt ağırlıklarına göre sıralanmasında kullanılmıştır. Çalışmada, uluslararası lojistik sektöründe faaliyet gösteren bir şirket için lojistik operasyon elemanı alımı örnek vakası üzerinde de çalışılmıştır. Ancak kriterler ve işe alım pozisyonu genel tutulmuştur. Ancak, her pozisyonun kendine özel yetkinlikleri ve bu yetkinliklerin pozisyonun gereksinimleri doğrultusunda olması gereken ağırlıkları vardır. Çaylan ve Yıldız (2016) lojistik iş gücü seçiminde mevcut ve yeni kriterlerin değerlendirmesi için lojistik sektöründen uzmanlarla görüşmeler yapmışlardır. Sonuç olarak, iş konusunda bilgi, deneyim, İngilizce bilgisinin yanı sıra takım çalışması, ilişki yönetimi ve iletişim becerilerinin önemli olduğunu belirlemişlerdir. Ayrıca, kültürel değişikliklere uyum, yenilikçi düşünme ve yetkinlik odaklı lojistik eğitimine sahip olma gibi yeni kriterlerin de önem kazandığını vurgulamışlardır. Ilgaz (2018) da lojistik sektöründe personel seçimi için AHP ve TOPSIS (Technique for order preference by similarity to ideal solution) yöntemlerini kullanarak çok kriterli bir model geliştirmiştir ve en önemli kriterin mesleki yeterlilik olduğunu belirtmiştir. Ayrıca, mesleki yeterlilik kriteri içinde en önemli alt kriterlerin ise mesleki eğitim ve lojistik teknolojilerini kullanabilme olduğunu ortaya çıarmıştır. Korkmaz (2019) ise Mersin'deki bir lojistik firmasında en uygun adayın seçilmesi için TOPSIS yöntemini kullanarak bir model oluşturmuştur. Tüm bu çalşsmalar her ne kadar konu olarak lojistik sektöründe olsalar da satış dışındaki (operasyon, iş geliştirme vs.) alanlar için personel alımını içermektedir. Bu nedenle, Akar ve Çakır (2016), Çaylan ve Yıldız (2016), Ilgaz (2018) ve Korkmaz (2019)'un makaleleri bu çalısmada gerçekleştirilen konu ve yöntemle benzerlikler taşısa da, bu çalışma lojistik için satış personeli pozisyonuna odaklanması nedeniyle büyük bir farklılık oluşturmaktadır.

Lojistik operasyonlarının diğer özelleşmiş alanlarında ve tedarik zincirinin çeşitli aşamalarında da çok kriterli karar verme yöntemleri ile personel seçimi modelleri geliştirilmiştir. Örneğin, Efe ve Kurt (2018) bulanı AHP ve bulanık TOPSIS yöntemlerini kullanarak bir liman işletmesi için personel seçimi modeli geliştirmiştir. Efe ve Kurt (2018), inceledikleri vaka çalışmasında en önemli kriterlerin "kendine güven" ve "planlama ve organizasyon yeteneği" olduğunu bulmuştur. Kuşakçı vd. (2019) ise havacilık sektöründe personel seçimi karar problemini bulanık MULTIMOORA yöntemi ile modellemiştir. Havacılık sektöründe yapılan bir diğer çalş̧mada, Yıldırım vd. (2019) havacilık işletmelerinde destek personel seçimi problemi için ARAS (Additive Ratio Assesment) yöntemini kullanarak bir model geliştirmişlerdir. Tedarik zincirinin üretim aşamasında da personel seçimi ile ilgili çalışmalar yapılmıştır. Örneğin, Öztürk ve Kaya (2020) otomotiv sektöründe yedek parka üretimi yapan bir işletmede personel alımı için VIKOR yöntemini kullanmıştır. Bir diğer çalışmada ise, Ulutaş (2019) bir mobilya atölyesi için en uygun pazarlama yöneticisi bulunması için Entropi ve MABAC (Multi-attributive border approximation area comparison) yöntemleri ile personel seçimi yapmışır.

Bu makale, literatürde incelenen çalışmalardan farklı olarak AHP yöntemi lojistik operasyonlarda çalışan satış personelinin yetkinlikleri ve işe alım sürecinde şirkete en uygun olan adayın belirlenmesi için kullanılmakta ve literatürdeki diğer çalışmalardan ayrışmaktadır. Bir sonraki bölüm bu makalede kullanılan yöntemi özetlemektedir.

\section{Yöntem}

Bu çalışmada işe alım yetkinliklerinin kriter ağırlıklarının belirlenmesi ve en uygun adayın seçilmesi için AHP yöntemi kullanılmıştır. Thomas Saaty (1980) tarafından geliştirilen AHP yöntemi, çok kriterli karar verme yöntemleri içinde en çok kullanılanlarından biridir. AHP yönteminin temelinde kriterlerin veya alternatiflerin ikili olarak karşılaştırılması yer almaktadır (Adamcsek, 2008).

AHP yönteminde önce alternatifler ve bunları değerlendirme sürecinde kullanacak olan kriterler belirlenir. Hedefe ulaşmak için mevcut olan alternatiflerden en iyisi seçilmektedir. Ana kriterlerin altında alt kriterleri de kapsayan örnek bir kriter yapısı Şekil 1'de gösterilmiştir. 
Hedef:

Ana Kriterler:

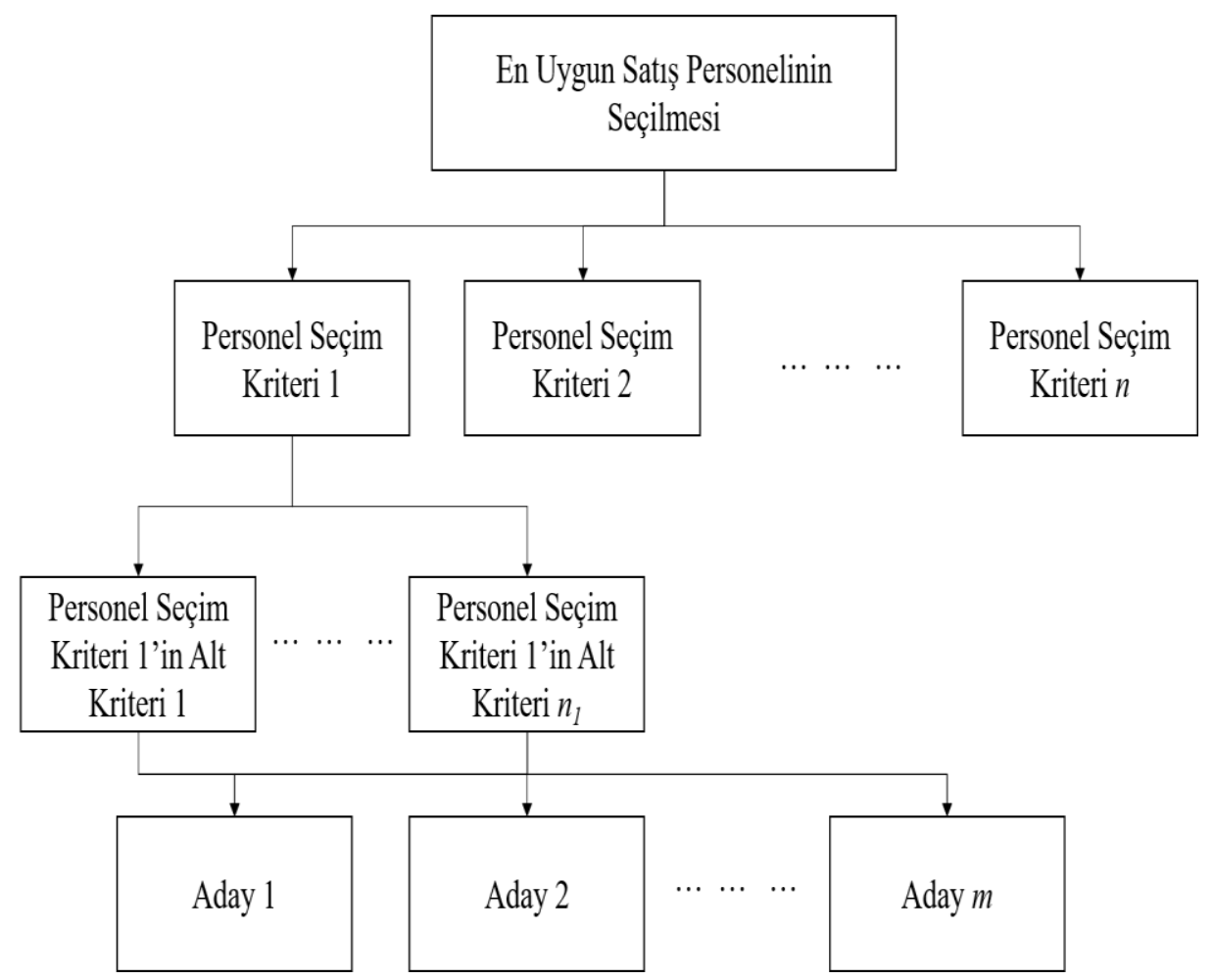

Şekil 1. Bu çalssmada gerçekleștirilen AHP süreci

Ardından ikili karşılaştırmalar yapılarak kriter ağırlıkları oluşturulur. Bu kapsamda karar verici Tablo 1'de verilen ölçeği kullanarak kriterleri birbiri ile ikili şekilde karşılaştırmaktadır.

Tablo 1. Göreceli Önem Ölçekleri Tablosu (Saaty, 2008)

\begin{tabular}{ll}
\hline Önem Derecesi & Tanım \\
\hline 1 & Eşit önemde veya aralarında kayıtsız kalınıor. \\
\hline 3 & Birinci, diğerinden biraz daha önemli veya biraz daha tercih ediliyor. \\
\hline 5 & Fazla önemli veya fazla tercih ediliyor. \\
\hline 7 & Çok fazla önemli veya çok fazla tercih ediliyor. \\
\hline 9 & Aşırı derecede önemli veya aşırı derecede tercih ediliyor. \\
\hline $2,4,6,8$ & Ara değerler \\
\hline
\end{tabular}

AHP Yönteminin adımları aşağıda detaylı şekilde verilmiştir.

Adım 1: Kriterlerin (veya alternatiflerin) karşılaştırılmasını içeren ilk adımda, her kriter birbiri ile ikili şekilde karşılaştırllır. Bu nedenle, $n$ kriterli bir karar probleminde boyutu $n \times n$ olan bir ikili karşılaştırma matrisi oluşturulur. İkili karşılaştırma sırasında Tablo 1'de verilen ölçek kullanılır. Bu adımın sonunda, ikili karşılaştırma matrisi $A$ aşağıdaki gibi oluşturulmuş olur:

$$
A=\left[\begin{array}{cccc}
a_{11} & a_{12} & \ldots & a_{1 n} \\
a_{21} & a_{22} & \ldots & a_{2 n} \\
\ldots & \ldots & \ldots & \ldots \\
a_{n 1} & a_{n 2} & \ldots & a_{n n}
\end{array}\right]
$$

Önemli bir not olarak belirtilmelidir ki, $a_{i j}=\frac{1}{a_{j i}}$ olarak belirlenmektedir. Örneğin, birinci kriter ikinciden çok fazla derecede önemli ise $a_{12}=7$ olmaktadır. Buna karşılık, ikinci kriter ile birinci kriterin karşılaştırmasında ise $a_{21}=1 / 7$ olmaktadır.

Adım 2: Bu adımda kriter ağırlıkları belirlenmektedir. Bunun için, ikili karşılaştırma matrisinde oluşturulan sütun vektörleri kullanılmaktadır. Sonuç olarak, her bir kriter $i$ için $n$ boyutlu $B_{i}$ sütun matrisi aşağıdaki gibi elde edilmektedir: 


$$
B_{i}=\left[\begin{array}{c}
b_{1 \mathrm{i}} \\
b_{2 \mathrm{i}} \\
b_{3 \mathrm{i}} \\
\cdots \\
b_{n i}
\end{array}\right]
$$

Sütun vektörünün her değeri $b_{i j}=\frac{a_{i j}}{\sum_{i=1}^{n} a_{i j}}$ formülü ile normalize edilmiştir. Her kriter için $B_{i}$ vektörünün oluşturulmasından sonra, bu vektörler birleştirilerek aşağıdaki $C$ matrisi elde edilmektedir:

$$
C=\left[\begin{array}{ccccc}
c_{11} & c_{12} & c_{13} & \ldots & c_{1 n} \\
c_{21} & c_{22} & c_{23} & \ldots & c_{2 n} \\
c_{31} & c_{31} & c_{33} & \ldots & c_{3 n} \\
\ldots & \ldots & \ldots & \ldots & \ldots \\
c_{n 1} & c_{n 2} & c_{n 3} & \ldots & c_{n n}
\end{array}\right]
$$

$C$ matrisinin değerleri aşağıdaki gibi bulunmaktadır:

$$
\begin{aligned}
& c_{11}=b_{11} \\
& c_{n 1}=b_{n 1} \\
& c_{1 n}=b_{1 n} \\
& c_{n n}=b_{n n}
\end{aligned}
$$

Kriter ağılıklarını içeren $W$ vektörünün bulunması için, $C$ matrisinin her satırının aritmetik ortalaması aşağıdaki formül kullanılarak hesaplanır:

$$
w_{i}=\frac{\sum_{j=1}^{n} c_{i j}}{n}
$$

Böylece, $W$ sütun vektörü kriter ağırllğı $\left(w_{i}\right)$ değerleri birleştirecek şekilde oluşturulur:

$$
W=\left[\begin{array}{c}
w_{1} \\
w_{2} \\
w_{3} \\
\cdots \\
w_{n}
\end{array}\right]
$$

Adım 3: Bu adımda tutarlılık oranı (TO) değeri hesaplanır. Yukarıda da belirtildiği gibi, AHP yöntemi karar vericinin ikili karş̧laştırmalarına dayanır. Bu nedenle yöntemin başarısı bu karşılaştırmaların tutarlı olmasına bağlıdır. Tutarlılık oranını hesaplarken öncelikle $A$ ve $W$ matrislerinin birbirleri ile çarpılmasından oluşan $D$ matrisi oluşturulur:

$$
D=\left[\begin{array}{cccc}
a_{11} & a_{12} & \ldots & a_{1 n} \\
a_{21} & a_{22} & \ldots & a_{2 n} \\
\ldots & \ldots & \ldots & \ldots \\
a_{n 1} & a_{n 2} & \ldots & a_{n n}
\end{array}\right] \times\left[\begin{array}{c}
w_{1} \\
w_{2} \\
w_{3} \\
\ldots \\
w_{n}
\end{array}\right]
$$

Sonrasında, $D$ matrisindeki değerler $\left(d_{i}\right)$ ve ağırlıklar $\left(w_{i}\right)$ kullanılarak her kriter için $E_{i}$ değerleri aşağıdaki gibi oluşturulur:

$$
E_{i}=\frac{d_{i}}{w_{i}}
$$

$E_{i}$ değerlerinin aritmetik ortalamasını bularak $\lambda$ değeri aşağıdaki şekilde hesaplanır:

$$
\lambda=\frac{\sum_{i=1}^{n} E_{i}}{n}
$$

Ardından, $\lambda$ değeri kullanılarak tutarlılık endeksi (TE) değeri aşağıdaki formül yardımı ile hesaplanır:

$$
T E=\frac{\lambda-\mathrm{n}}{n-1}
$$


Tutarlılık oranı değeri ise yukarıda hesaplanan TE değerinin Tablo 2'de verilen rassallık endeksi (RE) değerine bölünmesi ile bulunur:

$$
T O=\frac{\mathrm{TE}}{R E}
$$

Tablo 2. Rassallk endeksi (RE) değerleri (Saaty, 2008)

\begin{tabular}{llllllllllll}
\hline $\mathbf{n}$ & $\mathbf{1}$ & $\mathbf{2}$ & $\mathbf{3}$ & $\mathbf{4}$ & $\mathbf{5}$ & $\mathbf{6}$ & $\mathbf{7}$ & $\mathbf{8}$ & $\mathbf{9}$ & $\mathbf{1 0}$ & $\mathbf{1 1}$ \\
\hline $\mathbf{R E}$ & 0 & 0 & 0.58 & 0.9 & 1.12 & 1.24 & 1.32 & 1.41 & 1.45 & 1.49 & 1.51 \\
\hline
\end{tabular}

TO değerinin 0,10'dan küçük veya eşit olması, yapılan karşılaştırmanın tutarlı olduğuna ve yapılan analizin anlamlı olduğuna işaret eder. Aksi halde, karşılaştırmalar tutarsızdır ve analizden çıkarılan sonuçlar geçersizdir.

Adım 4: Yukarıdaki ilk üç adım kullanılarak, her kriter için her bir alternatif birbirleri ile karşılaştırılır. Bunun ardından her bir alternatifin her kriter için skorlarını içeren standardize edilmiş karar matrisi $(K)$ aşağıdaki gibi oluşturulur:

$$
K=\left[\begin{array}{ccccc}
s_{11} & s_{12} & s_{13} & \ldots & s_{1 n} \\
s_{21} & s_{22} & s_{23} & \ldots & s_{2 n} \\
\ldots & \cdots & \ldots & \cdots & \cdots \\
s_{m 1} & s_{m 2} & s_{m 3} & \cdots & s_{m n}
\end{array}\right]
$$

Adım 5: Adım 4'te oluşturulan $K$ matrisi, kriter ağırlıklarını içeren $W$ matrisi ile çarpılır ve alternatiflerin toplam skorlarının oluşturulduğu $L$ vektörü aşağıdaki gibi elde edilir:

$$
L=\left[\begin{array}{ccccc}
s_{11} & s_{12} & s_{13} & \ldots & s_{1 n} \\
s_{21} & s_{22} & s_{23} & \ldots & s_{2 n} \\
\ldots & \ldots & \ldots & \ldots & \ldots \\
s_{m 1} & s_{m 2} & s_{m 3} & \ldots & s_{m n}
\end{array}\right] \times\left[\begin{array}{c}
w_{1} \\
w_{2} \\
w_{3} \\
\ldots \\
w_{n}
\end{array}\right]=\left[\begin{array}{c}
w_{1} s_{11}+w_{2} s_{12}+w_{3} s_{13}+\cdots+w_{n} s_{1 n} \\
w_{1} s_{21}+w_{2} s_{22}+w_{3} s_{23}+\cdots+w_{n} s_{2 n} \\
\ldots \\
w_{1} s_{m 1}+w_{2} s_{m 2}+w_{3} s_{m 3}+\cdots+w_{n} s_{m n}
\end{array}\right]
$$

Sonuç olarak, L vektöründe bulunan toplam skorlardan en yükseğine sahip alternatif ilgili karar probleminin çözümü olarak elde edilmiş olur.

Bir sonraki bölümde merkezi Ege Bölgesi'nde olan ancak ulusal ve uluslararası alanda faaliyet gösteren ve sektöründe lider bir lojistik şirketinde yapılan örnek vaka çalşsması sunulmuştur.

\section{Vaka Çalışması ve Sonuçlar}

Bu çalışmada çok kriterli karar verme yöntemlerinden biri olan AHP yöntemi kullanılarak bir lojistik şirketinde satış personelinin işe alım sürecinde adayların sahip olması gerekli görülen kriterlerin, kurum değerleri nezdinde göreceli olarak değerlendirilebilmesi ve işe alım sürecindeki insan merkezli hataların ortadan kaldırılması amaçlanmaktadır. Bu noktada, bu çalışmada önerilen yöntemin doğrulanabilmesi için vaka çalışması lojistik sektöründe hem ulusal hem uluslararası platformda faaliyet gösteren sektöründe önde gelen bir şirkette gerçekleştirilmiştir. Şirkette satış bölümünde çalısmak üzere başvuran adaylar bu çalışmada önerilen yöntem ile değerlendirilmiş ve sonuçlar paylaşılmıştır.

Örnek vaka çalışmasında iki farklı satışçı profili incelenmiştir. Gerçek personel alım süreci verileri kullanılarak, hem deniz hem kara yolu hizmetlerinde çalısacak satış personeli adayları için yetkinliklerin belirlenmesi ve hiyerarşik kriter yapısının oluşturulması amaçlanmıştır. Bu şekilde deniz ve kara yolu için ana kriterlerin ve alt kriterlerin birbirlerine göre önem ağırlıkları belirlenmiş ve iki farklı pozisyon için gerekli kriterlerin farklı olabileceği gösterilmiştir. Deniz yolu ve kara yolu satış personeli için üçer adayın belirlenen kriterler bazında ikili karşılaştırma yapılması ile her iki pozisyon için de en uygun aday seçilmiştir.

Bu iki pozisyon için de yetkinlikler belirlenirken literatürden yararlanıldığı gibi, şirketin yöneticileri ile de görüşülerek dört temel kriter altında 20 alt kriter değerlendirilmiştir. Bu kriterlerin tamamı Şekil 2'de verilmiştir. Dört temel kriter şu şekilde sıralanmıştır: (1) Ortak iş yetkinlikleri, (2) Fonksiyonel Operasyonel yetkinlikler, (3) Ölçülebilir yetkinlikler ve (4) Bireysel yetkinlikler. Ortak iş yetkinlikleri ana kriteri takım oyuncusu olmak, planlama ve organize etmek, organizasyonel bağllık, iş ve süreç bilgisi ve dış görünüm alt kriterlerinden oluşmaktadır. Fonsiyonel ve operasyonel yetkinlikler içerisinde sonuç ve çözüm 
odaklılık, kriz yönetimi, öngörü ve muhakeme yeteneği, güvenilirlik ve tutarlılık, satış sonrası ilişki yönetimi yetkinlikleri incelenmektedir. Ölçülebilir yetkinlikler ana kriteri deneyim y1lı, eğitim düzeyi, yabancı dil bilgisi ve MS Office programları kullanabilme becerisi olarak alt kriterlere ayrılmaktadır. Şirket içindeki satış personelinin ortak iş yetkinlikleri, fonksiyonel yetkinlikleri ve ölçülebilir yetkinliklerinin yanı sıra aşağıda sıralanmış olan bireysel yetkinliklere sahip olmalarını beklenmektedir. Bireysel yetkinlikler ana kriteri eleştiriye açıklık, ikna kabiliyeti, stres yönetimi, ticari zeka, inisiyatif kullanabilme ve yazılı/sözlü iletişim becerisi alt kriterlerinden oluşmaktadır.

Deniz ve Kara taşıma satış personelleri için yapılan vaka çalışmaları 4.1 ve 4.2 Bölümlerinde ayrıntılı olarak anlatılmıştır. AHP yöntemi kullanılarak yetkinliklerin ağırlıklandırılması sırasında ve adayların karşılaştırılarak skorlarının belirlenmesi sürecinde Klaus D. Goepel tarafindan ilk olarak 2011 y1lında geliştirilmiş olan "AHP Calculator”4 isimli Microsoft Excel tabanlı yazılım kullanılmıştır.

Ağırlıklar belirlenirken her bir kriterin hiyerarşik yapıya göre kendi seviyesindeki diğer kriterlerle ikili karşılaştırılması ve bu şekilde matrislerin oluşturulması yöntemi izlenmektedir. Hiyerarşik yapının en üst seviyesinden başlanarak karşılaştırma matrisleri oluşturulmaktadır. İlgili karşılaştırmalar öncelikle ana faktörlerin kendi aralarında karşılaştırılması ile değerlendirilmekte olup AHP yöntemi ile kriter ağırlıkları hesaplanmaktadır. Daha sonra bu yöntem, her ana kriterin alt kriterleri arasında uygulanmakta olup AHP yöntemi kullanılarak ikili karşılaştırmalar yoluyla değerlendirilmektedir. En son olarak da, işe başvuran adaylar AHP yöntemi ile ikili olarak karşılaştırılmakta ve her kriter için skorları ilgili kriter ağırlıkları ile ağırlıklandırılarak adayın toplam skoru bulunmaktadır. En yüksek skoru alan aday seçilmektedir.

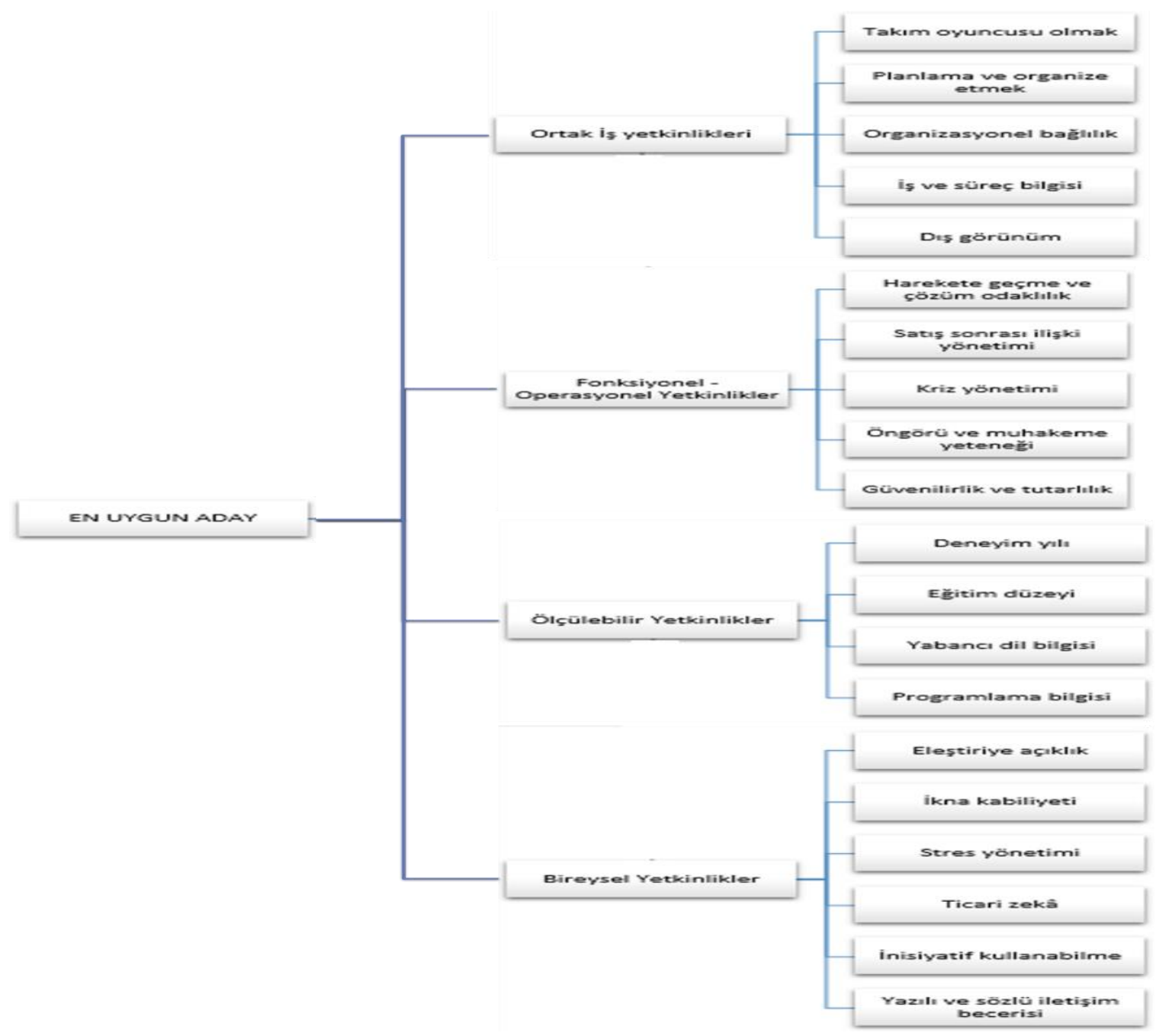

Şekil 2. Uygun Adaylarn Seçimini Etkileyen Kriterlerin ve Alt Kriterlerin Hiyerarşik Yapısı 
İki ayrı vaka analizi ile deniz ve kara yolu taşımacıllı̆ında değerlendirilecek adaylardan en uygun olan üç satış personeli adayı için karşılaştırmalar yapılmıştır. Kriterlerin ağırlıklandırılması ve adayların karşılaştırılmaları, şirket bünyesinde çalışmakta olan ve işe alımda yetkili karar vericilerin ortak kararı ile belirlenmiştir.

\section{Deniz Yolu Taşımacılı̆̆ında Satı̧̧ Personeli Profiline İlişkin Yetkinlik Karşılaştırmalarının Yapılmas1}

Ana kriterler olan ortak iş yetkinlikleri (OIY), fonksiyonel-operasyonel yetkinlikler (FOY), bireysel yetkinlikler (BY) ve ölçülebilir yetkinlikler (ÖY) kendi aralarında ikili şekilde karşılaştırılarak ikili karşılaştırma matrisi oluşturulmuştur. Şekil 3'te ana kriterlerin birbirleri arasındaki önem dereceleri gösterilmektedir. Örneğin, A sütununda FOY, B sütununda yer alan BY’ye göre 7 (çok üstün) üstündür. Şekil 4'te ise AHP hesaplamalarının Excel formülleri ile hesaplanmış halleri sunularak kriterlerin ağırlıkları verilmiștir. Daha önce de belirtildiği gibi tüm bu hesaplamalar MS Excel tabanlı bir AHP hesaplayıcı ile gerçekleştirilmiştir ve hesaplayıcı programın ekran görüntüleri Şekil 3 ve 4'te gösterilmiştir. Şekil 4'te de görüldüğü gibi tutarlılık oranı \%4.3 olarak çıkmış ve \%10’un altında olduğu için kabul edilebilir bir tutarll11k derecesidir.

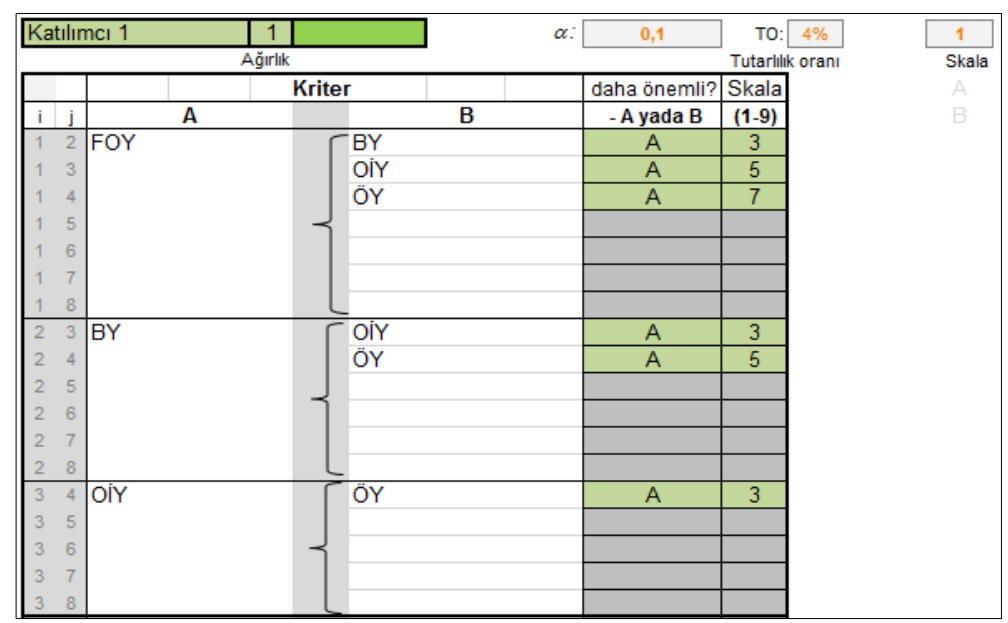

Şekil 3. Deniz Yolu Taşımacılĭğ Satış Personeli Seçimi için Ana Kriterlerin AHP Yöntemi ile İkili Karşsılaşttrmalar

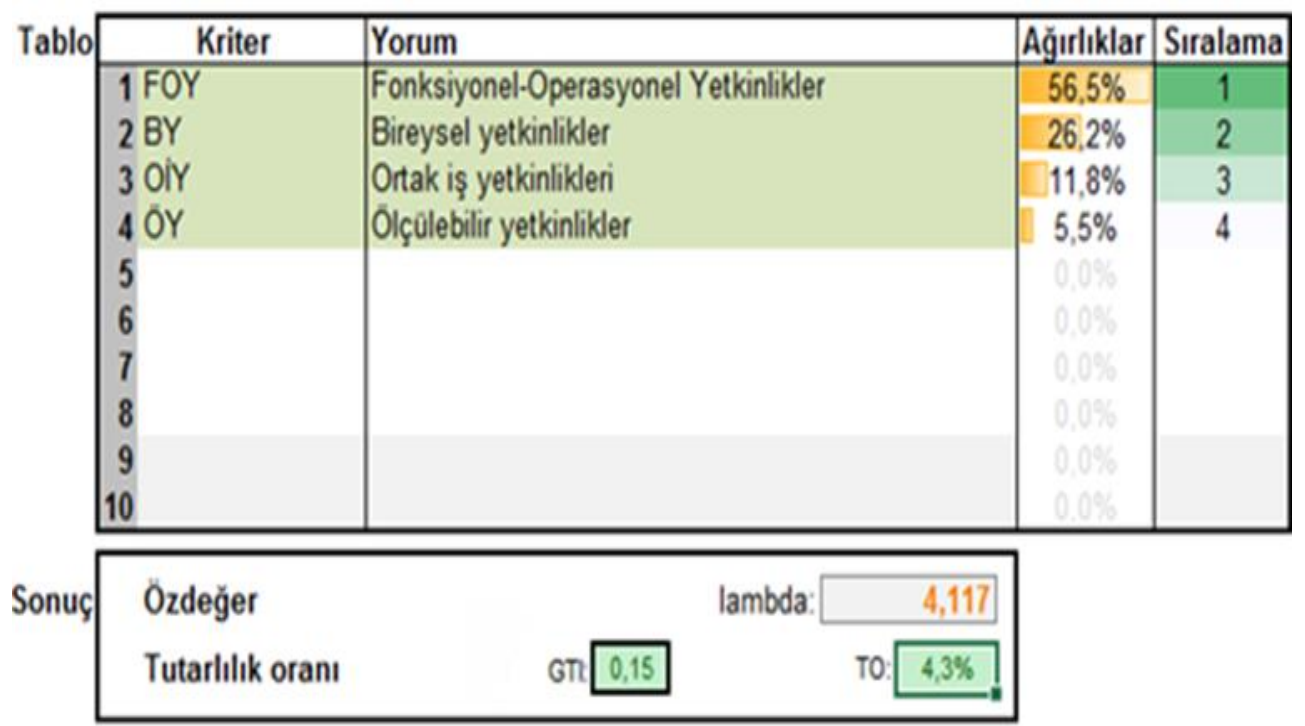

Şekil 4. Deniz Yolu Taşımacıllŭg Satış Personeli Seçimi için Ana Kriterlerin AHP Yöntemi ile Hesaplanmıs Ağrrlkklar

Deniz yolu taşımacilı̆̆ satış personeli seçimi için diğer alt kriterlerin ağırllkları da benzer şekilde hesaplanmıştır. Yine benzer şekilde, adaylar her alt kriter için birbirleriyle ikili karşılaştırma yöntemi ile karşılaştırılmış ve her adayın her kriter için skoru ortaya çıkarılmıştır. Belirtilmelidir ki, tüm bu 
hesaplamalarda tutarlılık oranları \%10'un altında kalmıştır. Tablo 2 hem tüm alt kriterlerin ağırlıklarını hem de tüm adayların ikili karşılaştırma yöntemi ile tüm kriterden aldıkları skorları göstermektedir.

Buna bağlı olarak adayların ağılıklandırılmış toplam skorları Aday 1 için \%42,26, Aday 2 için \%24,80 ve Aday 3 için \%32,94 olmuştur. En yüksek skoru alan Aday 1 olduğu için deniz yolu satış personeli pozisyonu için seçilen aday birinci aday olmuştur.

\section{Kara Yolu Taşımacıllı̆ında Satış Personeli Profiline İlişkin Yetkinlik Karşılaştırmalarının Yapilmasi}

Bu vaka analizinde kara yolu taşımacıllı̆ında değerlendirilecek adaylardan en uygun olan üç satış personeli adayı için karşılaştırmalar yapilmaktadır. Deniz yolu hizmetlerinde çalışacak olan satış personelinden farklı olarak alt kriterlerin ağırlıkları kara yolu taşımacılı̆̆ında çalışacak satış personelinden farklılık göstermektedir. Bu bağlamda ana kriterlerin ağırlıkları değişmemekle birlikte, alt kriterlerin ikili ağırlıkları farklılık göstermektedir. Alt kriter ağırlıklarındaki bu farklılığın şirket yöneticileri tarafindan belirlenmesi ise önerdiğimiz yöntemin önemini ve gerçek hayattaki kullanılabilirliğini göstermektedir.

Deniz yolu taşımacıllı̆ı satış personeli seçiminde kullanılan yönteme benzer şekilde, kara yolu taşımacıllığı satış personeli seçiminde de alt kriterlerin ağırlıkları hesaplanmıştır. Yine benzer şekilde, adaylar her alt kriter için ikili karşılaştırma yöntemi kullanılarak birbirleriyle karşılaştırılmış ve her adayın her kriter için skoru ortaya çıkarılmıştır. Tüm ikili karşılaştırmalarda tutarlılık oranları \%10’un altında kalmış ve kabul edilir bir tutarlılık derecesine ulaşılmıştır. Tablo 3, kara yolu taşımacılı̆̆ satış personeli için hem tüm alt kriterlerin ağırlıklarını hem de her adayın ikili karşılaştırma yöntemi ile tüm kriterden aldığı skorları göstermektedir. Tabloda, kara yolu satış personeli için bulunan alt kriter ağırlıklarının deniz yolu için bulunan ağırlıklardan belirgin derecede farklı olduğu görülmektedir.

Buna bağlı olarak adayların ağırlıklandırılmıș toplam skorları Aday 1 için \%22,71, Aday 2 için \%34,53 ve Aday 3 için \%42,81 olmuştur. En yüksek skoru alan Aday 3 olduğu için kara yolu satış personeli pozisyonu için seçilen aday birinci aday olmuştur.

Tablo 2. Deniz Yolu Hižmetleri Satış Personeli Alım için Belirlenen Kriterlerin Ağırlıklar ve Adaylarn Tüm Kriterler için Skorlarn

\begin{tabular}{|c|c|c|c|c|}
\hline Kriterler & Kriter ağırlığ1 & Aday 1 & Aday 2 & Aday 3 \\
\hline ORTAK ISS YETKINLLIKLERİ & $11,80 \%$ & & & \\
\hline Takım oyuncusu olmak & $5,30 \%$ & $75,20 \%$ & $17,80 \%$ & $7,00 \%$ \\
\hline Planlama ve organize etmek & $12,60 \%$ & $66,90 \%$ & $8,80 \%$ & $24,30 \%$ \\
\hline Organizasyonel bağlllık & $37,10 \%$ & $63,70 \%$ & $25,80 \%$ & $10,50 \%$ \\
\hline İş ve süreç bilgisi & $37,10 \%$ & $19,60 \%$ & $49,30 \%$ & $31,10 \%$ \\
\hline Diş görünüm & $7,90 \%$ & $20,00 \%$ & $40,00 \%$ & $40,00 \%$ \\
\hline FONKSIYONEL-OPERASYONEL YETKINNLIKLER & $56,50 \%$ & & & \\
\hline Harekete geçme ve çözüm odaklılık & $36,20 \%$ & $54,00 \%$ & $16,00 \%$ & $30,00 \%$ \\
\hline Satı̧s sonrası ilişki yönetimi & $3,90 \%$ & $63,70 \%$ & $25,80 \%$ & $10,50 \%$ \\
\hline Kriz yönetimi & $7,60 \%$ & $73,10 \%$ & $18,80 \%$ & $8,10 \%$ \\
\hline Öngörü ve muhakeme yeteneği & $16,10 \%$ & $25,00 \%$ & $25,00 \%$ & $50,00 \%$ \\
\hline Güvenilirlik ve tutarllık & $36,20 \%$ & $33,33 \%$ & $33,34 \%$ & $33,33 \%$ \\
\hline BIREYSEL YETKINLIKLER & $26,20 \%$ & & & \\
\hline Eleştriye açıklık & $2,20 \%$ & $73,10 \%$ & $18,80 \%$ & $8,10 \%$ \\
\hline İkna kabiliyeti & $34,80 \%$ & $25,80 \%$ & $10,50 \%$ & $63,70 \%$ \\
\hline Stres yönetimi & $11,10 \%$ & $73,10 \%$ & $18,80 \%$ & $8,10 \%$ \\
\hline Ticari zeka & $10,50 \%$ & $10,50 \%$ & $25,80 \%$ & $63,70 \%$ \\
\hline İnisiyatif kullanabilme & $6,60 \%$ & $10,50 \%$ & $25,80 \%$ & $63,70 \%$ \\
\hline Yazılı ve sözlü iletişim becerisi & $34,80 \%$ & $67,20 \%$ & $26,50 \%$ & $6,30 \%$ \\
\hline ÖLÇÜLEBİLIR YETKINLİKLER & $5,50 \%$ & & & \\
\hline Deneyim y1l & $42,70 \%$ & $16,30 \%$ & $29,70 \%$ & $54,00 \%$ \\
\hline Eğitim düzeyi & $29,30 \%$ & $5,50 \%$ & $29,00 \%$ & $65,50 \%$ \\
\hline Yabanc1 dil bilgisi & $24,20 \%$ & $14,30 \%$ & $57,10 \%$ & $28,60 \%$ \\
\hline Programlama bilgisi & $3,80 \%$ & $60,00 \%$ & $20,00 \%$ & $20,00 \%$ \\
\hline
\end{tabular}


Tablo 3. Kara Yolu Hiz̧metleri Satıs Personeli Alımı için Belirlenen Kriterlerin Ağırlılar ve Adaylarn Tüm Kriterler için Skorlar

\begin{tabular}{|c|c|c|c|c|}
\hline Kriterler & Kriter ağırlığ1 & Aday 1 & Aday 2 & Aday 3 \\
\hline ORTAK ISS YETKİNLİKLERİ & $11,80 \%$ & & & \\
\hline Takım oyuncusu olmak & $14,80 \%$ & $73,06 \%$ & $8,10 \%$ & $18,84 \%$ \\
\hline Planlama ve organize etmek & $10,20 \%$ & $63,70 \%$ & $25,83 \%$ & $10,47 \%$ \\
\hline Organizasyonel bağll1ık & $34,90 \%$ & $64,91 \%$ & $27,90 \%$ & $7,19 \%$ \\
\hline İş ve süreç bilgisi & $34,90 \%$ & $6,29 \%$ & $67,16 \%$ & $26,54 \%$ \\
\hline Dış görünüm & $5,20 \%$ & $20,00 \%$ & $40,00 \%$ & $40,00 \%$ \\
\hline FONKSIYONEL-OPERASYONEL YETKINLIIKLER & $56,50 \%$ & & & \\
\hline Harekete geçme ve çözüm odaklılık & $36,20 \%$ & $10,47 \%$ & $25,83 \%$ & $63,70 \%$ \\
\hline Satış sonrası ilişki yönetimi & $7,70 \%$ & $58,16 \%$ & $10,95 \%$ & $30,90 \%$ \\
\hline Kriz yönetimi & $16,10 \%$ & $7,19 \%$ & $27,90 \%$ & $64,91 \%$ \\
\hline Öngörü ve muhakeme yeteneği & $3,90 \%$ & $10,47 \%$ & $25,83 \%$ & $63,70 \%$ \\
\hline Güvenilirlik ve tutarlılık & $36,20 \%$ & $25,83 \%$ & $63,70 \%$ & $10,47 \%$ \\
\hline BİREYSEL YETKİNLİKLER & $26,20 \%$ & & & \\
\hline Eleştriye açıklık & $2,57 \%$ & $73,06 \%$ & $8,10 \%$ & $18,84 \%$ \\
\hline İkna kabiliyeti & $40,56 \%$ & $7,19 \%$ & $27,90 \%$ & $64,91 \%$ \\
\hline Stres yönetimi & $5,99 \%$ & $10,47 \%$ & $63,70 \%$ & $25,83 \%$ \\
\hline Ticari zeka & $12,78 \%$ & $7,19 \%$ & $27,90 \%$ & $64,91 \%$ \\
\hline İnisiyatif kullanabilme & $20,28 \%$ & $7,19 \%$ & $27,90 \%$ & $64,91 \%$ \\
\hline Yazllı ve sözlü iletişim becerisi & $17,82 \%$ & $56,95 \%$ & $9,74 \%$ & $33,31 \%$ \\
\hline ÖLÇÜLEBİLİR YETKİNLİKLER & $5,50 \%$ & & & \\
\hline Deneyim yill & $52,42 \%$ & $60,00 \%$ & $20,00 \%$ & $20,00 \%$ \\
\hline Eğitim düzeyi & $30,30 \%$ & $6,29 \%$ & $26,54 \%$ & $67,17 \%$ \\
\hline Yabanc1 dil bilgisi & $13,18 \%$ & $22,71 \%$ & $5,10 \%$ & $72,19 \%$ \\
\hline Programlama bilgisi & $4,10 \%$ & $33,33 \%$ & $33,33 \%$ & $33,34 \%$ \\
\hline
\end{tabular}

Deniz Yolu ve Kara Yolu Taşımacılığında Çalışacak Satış Personeli Profilindeki Farklılıkların Yorumlanması

Hem deniz yolu hem kara yolu taşımacılığında çalışmak için işe alım sürecine dâhil olan deniz yolu hizmetlerinde çalıșmak için bașvuran 3 adaya ve kara yolu hizmetlerinde çalıșmak için bașvuran 3 adaya yetkinlik bazlı AHP yöntemi uygulanmıştır. Deniz ve kara yolunda belirlenmiş olan alt kriterlerin birbirleri arasındaki ağırlıkları farklılık göstermiş olup ana kriterlerin ağırlıkları her iki satış personeli pozisyonu için sabit kalmıştır. Alt kriterlerin değişiklik göstermesinin nedeni satış personellerinin sahip olması gereken iş ve süreç bilgisinin farklılık göstermesinin yanı sıra deniz ve kara yolu müşteri portföyünün ve müşteri beklentilerinin farklı olmasından kaynaklanmıştır. Ana kriterlerin ağıllkkların hem deniz yolu hem kara yolu için aynı olmasının nedeni karar vericilerin satış personellerinden temel anlamda deniz veya kara yolu gözetmeksizin aynı temel yetkinlikleri sahip olmalarını beklemeleridir.

Deniz ve kara yolu hizmetlerinde çalışacak adayların sahip olması gereken yetkinlikler insan kaynakları ve satış alanındaki karar vericiler tarafindan ağırlıklandırlmış olup satış biriminde çalışacak bir aday için belirlenen en önemli ana yetkinliğin Fonksiyonel-Operasyonel yetkinlikler olduğu ortaya çımıştır. Tablo 2 ve Tablo 3'te kriter ağırlıkları incelendiğinde alt kriter ağırlıklarının deniz ve kara yolu hizmetlerinde çalışacak adaylar için farklılıkları açıkça görülmektedir. Alt kriterlerin ağırlıklandırılması sonucunda ise deniz yolu hizmetlerinde çalşsacak satış personelinden harekete geçme kabiliyetinin yüksek olması ve çözüm odaklı olmasının yanı sıra güvenilir ve tutarlı olması beklenmektedir. Kara yolu hizmetlerinde çalışacak adayların sahip olması gereken alt kriterlerin ağırlıklandırılması sonucunda ise bu birimde çalışacak satış personelinden harekete geçme kabiliyetinin yüksek olmasının ve çözüm odaklı olmasının yanı sıra güvenilir ve tutarlı olması beklenmektedir. Deniz yolu hizmetlerinde çalışacak personel yetkinliklerinden farklı olarak satış sonrası ilişkilerin kara yolu hizmetlerinde daha yüksek bir ağırllkla üstün olduğu sonucuna varılmaktadır. Benzer şekilde kriz yönetiminin sahip olduğu ağırlığın kara yolu hizmetlerinde deniz yolu hizmetlerine kıyasla daha yüksek olduğu görülmektedir. Diğer bir taraftan, vaka çalışmasının gerçekleştirildiği uluslararası lojistik firmasında çalışan, insan kaynakları ve satış alanında görev alan, işe alım sürecindeki karar vericiler deniz yolu hizmetlerinde çalışan satış personelinin kara yolu hizmetlerinde çalışan satış personeline kıyasla öngörü ve muhakeme yeteneklerinin daha yüksek olmasını beklemektedirler. 
Kriter ağırlıklarının farklılıklarının yanı sıra, işe alınacak kişinin belirlenmesinde adayların bireysel özellikleri de çok önemlidir. Bu nedenle, Tablo 4'te deniz ve kara yolu hizmetleri satış personeli alımı için bu çalışmada önerilen yöntem ile seçilen adayların özellikleri karşılaştırılmıştır. Seçilen adayların özelliklerinden de anlaşılacağı gibi, bu çalışmada önerilen yöntem ilgili satış alanı için istenen kriter özelliklerine sahip doğru adayların seçilmesine yardımcı olmaktadır.

Tablo 4. Deniz ve Kara Yolu Hižmetleri Satış Personeli Alımı için Seçilen Adaylarm Özelliklerinin Karşslasstırması

\begin{tabular}{|c|c|c|}
\hline \multirow[b]{2}{*}{ Kriterler } & \multicolumn{2}{|c|}{ Seçilen adayların özellikleri } \\
\hline & Deniz Yolu & Kara Yolu \\
\hline \multicolumn{3}{|l|}{ ORTAK İŞ YETKİNLİKLERİ } \\
\hline Takım oyuncusu olmak & $75,20 \%$ & $18,84 \%$ \\
\hline Planlama ve organize etmek & $66,90 \%$ & $10,47 \%$ \\
\hline Organizasyonel bağlllık & $63,70 \%$ & $7,19 \%$ \\
\hline İş ve süreç bilgisi & $19,60 \%$ & $26,54 \%$ \\
\hline Diş görünüm & $20,00 \%$ & $40,00 \%$ \\
\hline \multicolumn{3}{|c|}{ FONKSIYONEL-OPERASYONEL YETKINLLIKLER } \\
\hline Harekete geçme ve çözüm odaklılık & $54,00 \%$ & $63,70 \%$ \\
\hline Satış sonrası ilişki yönetimi & $63,70 \%$ & $30,90 \%$ \\
\hline Kriz yönetimi & $73,10 \%$ & $64,91 \%$ \\
\hline Öngörü ve muhakeme yeteneği & $25,00 \%$ & $63,70 \%$ \\
\hline Güvenilirlik ve tutarlılık & $33,33 \%$ & $10,47 \%$ \\
\hline \multicolumn{3}{|l|}{ BİREYSEL YETKINNLİKLER } \\
\hline Eleştriye açıklık & $73,10 \%$ & $18,84 \%$ \\
\hline İkna kabiliyeti & $25,80 \%$ & $64,91 \%$ \\
\hline Stres yönetimi & $73,10 \%$ & $25,83 \%$ \\
\hline Ticari zeka & $10,50 \%$ & $64,91 \%$ \\
\hline İnisiyatif kullanabilme & $10,50 \%$ & $64,91 \%$ \\
\hline Yazılı ve sözlü iletişim becerisi & $67,20 \%$ & $33,31 \%$ \\
\hline \multicolumn{3}{|l|}{ ÖLÇÜLEBİLİR YETKİNLİKLER } \\
\hline Deneyim yll & $16,30 \%$ & $20,00 \%$ \\
\hline Eğitim düzeyi & $5,50 \%$ & $67,17 \%$ \\
\hline Yabanc1 dil bilgisi & $14,30 \%$ & $72,19 \%$ \\
\hline Programlama bilgisi & $60,00 \%$ & $33,34 \%$ \\
\hline
\end{tabular}

\section{Sonuç}

Küresel rekabet ortamında şirket verimliliğinin sağlanabilmesinin temelinde insan kaynakları uygulamaları ve stratejilerinin büyük bir payı bulunmaktadır. İnsan faktörünün lojistik sektöründeki her faaliyet biriminde yer almasından dolayı bu faktörün etkin ve verimli bir şekilde yönetilmesi gerek şirket performansı gerek sektörün ülke içindeki katma değeri açısından büyük önem taşımaktadır. Stratejik hedeflere ulaşabilme doğrultusunda lojistik sektörünün payının büyüklüğü göz önünde bulundurulduğunda sektörde yaratılan istihdamın niteliğinin önemi de her geçen gün artmaktadır. Bu doğrultuda insan kaynakları yönetim birimlerinin şirketlerin finansal ve performans çıtılarına doğrudan etki edecek uygulamalar geliştirmeleri gerekmektedir.

Günümüzde, şirketler personel seçerken maliyetli ve fazlaca iş gücü gerektiren bir süreç ile karş1 karşıya kalmaktadırlar. İşe alım sürecinin herhangi bir pozisyon için en uygun adayı tespit edebilmesindeki başarısı kadar işe alımdan sonraki süreçte de aynı nitelikte uygulamalar geliştirilmesi gerekmektedir. $\mathrm{Bu}$ noktada şirket bünyesinde verilecek eğitimler ve geliştirilecek yenilikçi uygulamalar, kalifiye işgücü yaratarak sektörün ilerlemesine ivme katacaktır. Çok kriterli karar verme yöntemlerinin personel seçimi ve ișe alım süreçlerinde kullanılması, sürecin daha etkili ve hızlı șekilde sonuçlanması için bir alternatif yaratmaktadır.

Bu çalışmada lojistik sektöründe satış pozisyonu için işe alımlarda kullanılmak üzere AHP yöntemi kullanılarak çok kriterli bir karar verme yaklaşımı geliştirilmiştir. Çalışma bu haliyle lojistik sektöründe satış pozisyonu için işe alım sürecini kapsamlı bir şekilde ele almakta ve gerek konusu gerekse yöntemi açısından literatürdeki bir açığı doldurmaktadır. Önerilen yöntemi test etmek için, Ege Bölgesi’nde faaliyet gösteren ve sektöründe lider konumda bulunan uluslararası lojistik firmalarından birinin bünyesinde satış 
departmanında çalışmak için başvuru yapan ve işe alım sürecine dâhil olan adaylar arasından şirket için en uygun aday AHP yöntemiyle seçilmiştir. Bu noktada lojistik sektöründe bir satış personelinin sahip olması gereken yetkinlikler de karar vericiler tarafından ağırlıklandırılmıştır. Karar vericiler, kriterlerin ağırlıklandırılması esnasında şirketin stratejik hedefleriyle uyum sağlayacak adayın seçilmesi yönünde değerlendirmelerini yapmışlardır. Bu sürecin bir bölümünün insan faktörü etkisinde değerlendirildiği göz önünde bulundurulduğunda sürecin tamamen nesnel olması beklenmemektedir. Çünkü bazı kriterler doğası gereği öznel değerlendirmeyi gerektirirken bazı kriterler ise nesneldir (çalışma tecrübesi gibi). İncelenen gerçek vaka analizinde, yöntemin farklı pozisyonlar için nasıl uygulanacağını göstermek ve aynı şirkette farklı satış pozisyonları için gerekli yetkinliklerin nasıl değiştiğini gözlemlemek için deniz yolu ve kara yolu satış personeli olarak iki farklı işe alım süreci gerçek veriler kullanılarak incelenmiştir.

$\mathrm{Bu}$ araştırmanın sonuçlarından hem insan kaynakları yöneticileri hem de satış personeli adayları açısından bazı çıkarımlar yapmak mümkündür. Kriterlerin birbirlerine göre ağırlıkları, çalışmaya konu olan şirketin faaliyetleri kapsamı ve kurum kültürünün etkisinde kalmış olmakla birlikte model şirketin sektörde öncü ve köklü bir şirket olmasından dolayı kriter ağıllkklarından Türkiye'de lojistik sektörü hakkında genel bir fikir edinilmesini sağlamaktadır. Deniz yolu ve kara yolu hizmetleri açısından kriterlerin farklı olmasının nedenini ise ülkemizin coğrafi konumu itibariyle deniz yolu hizmetlerini kullanan müşterilerin ağırlıklı olarak yurtdışı portföyüne dâhil olmaları ve kara yolları hizmetlerinin ise benzer olarak ülkemizin coğrafi konumu göz önünde bulundurulduğunda yerli müşteri ağırlıklı bir portföye sahip olması olarak ifade etmek mümkündür. Müssteri portföyünün beklentilerindeki farklılıkların ve iletişim kanallarındaki çeşitliliğin doğrudan işe alma sürecine dâhil olan adayların yetkinliklerinin skor ağırlıklarını etkilemekte olduğu görülmektedir. Bu sonuçlar insan faktörünün sayısal bilimler temelli bir bilim ve sektör olan lojistik sektöründeki önemini göstermektedir.

Bu çalışmada kriterlerin ağıllkklandırılması ve adayların seçimi AHP yöntemi ile yapılmıştır. Ancak, aday sayısının artması halinde ikili karşılaştırmaların sayısı da artacaktır. Bu da ikili karşılaştırmalardaki tutarsılıkklara yol açabilecek ve aday seçimini daha zor hale getirebilecektir. Bu doğrultuda, bu çalışmanın bir uzantısı olarak kriter ağırlıkları belirlendikten sonra adaylar başka çok kriterli karar verme yöntemleri ile (örneğin, ELECTRE veya TOPSIS gibi) birbirleri içinde sıralanabilir. Ayrıca, bu çalışmada ele alınan örnek vaka analizinde sadece satı̧s personeli işe alım süreci dikkate alınmıştır. Önerilen bu model, vaka analizinin yapıldığ1 şirketin başka işe alım süreçlerinde (örneğin, operasyon veya bilgi işlem gibi) de uygulanabilir ve işe alım kriterlerinin farklılıkları ortaya konarak bir karşılaştırma yapılabilir. Buna bağlı olarak, şirketin tüm pozisyonlar için ortak aradığı kriterler de elde edilebilir. Ayrıca, yapılan vaka çalışmasının kapsamı genişletilerek başka lojistik şirketleri de incelenebilir ve böylece bu çalışmada bulunan kriterlerin sektörün genelinde geçerli olup olmadıkları da incelenebilir.

\section{Etik Beyan}

"Analitik Hiyerarşi Prosesi Yöntemi ile Lojistik Sektöründeki İdeal Satış Personeli Profiline Ulașmak: Uluslararası Bir Lojistik Firma Örneğ̨̆” başlıklı çalışmanın yazım sürecinde bilimsel, etik ve alıntı kurallarına uyulmuş; toplanan veriler üzerinde herhangi bir tahrifat yapılmamış ve bu çalş̧ma herhangi başka bir akademik yayın ortamına değerlendirme için gönderilmemiştir.

\section{Kaynakça}

Adamcsek, E. (2008). The analytic bierarcby process and its generalizations (Doktora Tezi). Eotvos Lorand University, Budapeşte. .

Arvis, J.F., Ojala, L., Wiederer, C., Shepherd, B., Raj, A., Dairabayeva, K. ve Kiiski, T. (2018). Connecting to compete 2018: Trade logistics in the global economy. World Bank Report, Erişim adresi: https://openknowledge.worldbank.org/bitstream/handle/10986/29971/LPI2018.pdf

Akar, G.S. ve Çakır, E. (2016). Lojistik sektöründe bütünleştirilmiş bulanık AHP-MOORA yaklaşımı ile personel seçimi. Yönetim ve Ekonomi Arasttrmalar Dergisi, 14(2), 185-199.

Boudreau, J. W. ve Ramstad, P. M. (2003). Strategic industrial and organizational psychology and the role of utility analysis models. İçinde I.B. Weiner (Edt.), Handbook of Psychology (ss. 193-221). Wiley Online Library.

Candemir, A., Zalluhoğlu, A. E. ve Yücel, E. (2015). Perakende sektöründe satış elemanlarının eğitimlerinin ve kişisel niteliklerinin satış başarısı üzerindeki etkisi: İzmir örneği. Afyon Kocatepe Üniversitesi İktisadi ve İdari Bilimler Fakiiltesi Dergisi, 17(2), 49-65.

Chen, C., Zhang, Z., Chen, L. ve Lv, Y. (2014). An effective human resource management mode via analytic hierarchy process. Computer Modelling \& New Technologies, 18(12C), 1309-1314.

Chyn, G. H. ve Kaliannan, M. (2011). Human resource management practices in logistic service provider industry: A case study. Interdisciplinary Journal of Contemporary Research in Business, 2(9), 32-44. 
Çaylan, Ö. D. ve Yıldız, R. Ö. (2016). An evaluation on the personnel selection criteria for third party logistics companies in Turkey: A qualitative research. Sosyal Bilimler Arasttrmalar Dergisi, 14, 59-81.

Dessler, G. (2012). Human resource management: Global edition. Edinburgh: Pearson.

Efe, B. ve Kurt, M. (2018). Bir liman işletmesinde personel seçimi uygulamasi. Karaelmas Science and Engineering Journal, $8(2), 417-427$.

Hellriegel, D., Jackson, S. E. ve Slocum, J. W. (2008). Management: A competency-based approach. Mason, OH: Thomson Higher Education.

İbicioğlu, H. ve Ünal, Ö. F. (2014). Analitik hiyerarşi prosesi ile yetkinlik bazlı insan kaynakları yöneticisi seçimi. Atatürk Üniversitesi İktisadi ve İdari Bilimler Dergisi, 28(4), 55-78.

Ilgaz, A. (2018). Lojistik sektöründe personel seçim kriterlerinin AHP ve TOPSIS yöntemleri İle değerlendirilmesi. Journal of Suleyman Demirel University Institute of Social Sciences, 32(1), 586-605.

Kahraman, C., Cebeci, U. ve Ulukan, Z. (2003). Multi-criteria supplier selection using fuzzy AHP. Logistics Information Management, 16(6), 382-394.

Kelemenis, A. ve Askounis, D. (2010). A new TOPSIS-based multi-criteria approach to personnel selection. Expert systems with applications, 37(7), 4999-5008.

Koban, E. ve Keser, H. Y. (2013). Rekabet edebilirlikte Türk lojistik sektörünün istihdam yapısının analizi ve istihdama yönelik devlet destekleri. Calisma İlişkileri Dergisi, 4(2), 32-43.

Korkmaz, O. (2019). Personnel selection method based on TOPSIS multi-criteria decision-making method. International Journal of Economic \& Administrative Studies, 23, 1-16.

Kuşakçı, A. O., Ayvaz, B., Öztürk, F. ve Sofu, F. (2019). Bulanık multimoora ile personel seçimi: Havacılık sektöründe bir uygulama. Niğde Ömer Halisdemir Üniversitesi Mühendislik. Bilimleri Dergisi, 8(1), 96-110.

Lin, H. T. (2010). Personnel selection using analytic network process and fuzzy data envelopment analysis approaches. Computers \& Industrial Engineering, 59(4), 937-944.

Öztürk, F. ve Kaya, G. K. (2020) Personnel selection with fuzzy VIKOR: An application in automotive supply industry. Gari Üniversitesi Fen Bilimleri Dergisi Part C: Tasarm ve Teknoloji, 8(1), 94-108.

Periatt, J. A., Chakrabarty, S. ve Lemay, S. A. (2007). Using personality traits to select customer-oriented logistics personnel. Transportation Journal, 46(1), 22-37.

Saaty, T. L. (1980). The analytic bierarchy process: Planning, priority setting, resource allocation. New York: McGraw-Hill International.

Saaty, T. L. (2008). Decision making with the analytic hierarchy process. International Journal of Services Sciences, 1(1), 8398.

Schmitt, N. (2007). The value of personnel selection: Reflections on some remarkable claims. Academy of Management Perspectives, 21(3), 19-23.

Ulutaş, A. (2019). Entropi ve MABAC Yöntemleri ile Personel Seçimi. OPUS Uluslararası Toplum Araştırmalar Dergisi, 13(19), 1552-1573.

Yıldırım, B. I., Uysal, F. ve Ilgaz, A. (2019). Havayolu işletmelerinde personel seçimi: Aras yöntemi ile bir uygulama. Süleyman Demirel Üniversitesi Sosyal Bilimler Enstitüsü Dergisi, 2(33), 219-231.

\section{EXTENDED ABSTRACT}

The logistics sector has been one of the fastest-growing sectors in both Turkey and the World for the last two decades. The globalization due to increased technology, commerce agreements between countries or within trade regions, the recent developments in the electronic commerce business, and the personal qualifications and knowledge of the logistics employees have become important factors to select logistics service providers for customers. Therefore, evaluation of the candidates for the jobs, and selection of the best employee among the candidates are among the most critical human resource management tasks in companies. In the current practice, selecting the right employee for the right job is ensured by human resource managers. One of the most important jobs of human resource managers is to objectively identify and select the best employee for a given job position and the company. Although there is no commonly accepted procedure to choose the best candidate for job positions among the logistics companies, this task has become not only important but also difficult because of the intense global competition and the increasing needs of the logistics sector.

Today's companies have a significantly costly and labor-intensive process during the personnel selection process for their open positions. In addition to the success of selecting the best candidate for a job, similar practices should also be made after selecting the employee. At this point, the training within the company and any other professional certificate program might help to develop a qualified workforce for the logistics sector. The usage of multi-criteria decision-making methods in personnel selection and job recruitment processes helps to have more effective and fast human resource management practices. 
This study focuses on sales personnel selection for logistics companies as the sales personnel is the main revenue generator for logistics companies, and therefore, crucial to the survival in the intense competition within the logistic sector. In this study, Analytical Hierarchy Process (AHP) has been used to determine the weights of the job selection criteria and selecting the best candidate for a given job according to the predetermined criteria and criteria weights. AHP has been developed by Thomas Saaty (1980) and it is one of the most used multi-criteria decision-making methods. The main calculation of the AHP method is the pairwise comparison of criteria or alternatives. The first step of the AHP method is to determine the criteria that are used to evaluate alternatives. The output of the method is the best alternative according to the given criteria and criteria weights.

In this study, an AHP based multi-criteria decision-making methodology has been developed to use in job recruitment processes for sales positions in the logistics sector. This study comprehensively addresses the job recruitment process of sales positions in logistics companies, and therefore, it contributes to the literature as this problem has not been adequately addressed by the previous studies. To test our proposed method, one of the leading logistics companies located in the Aegean Region has been selected and a case study is conducted. In this case study, the job applicants for the sales department have been evaluated using our proposed AHP based methodology. Also, the required qualifications - selection criteria - are determined by the decision-makers of the company, and criteria weights are calculated accordingly. During the process of weighting criteria, the decision-makers considered the best candidate who can work by the company's strategic goals. Considering the hiring process involves human judgment, this process cannot be entirely objective. Also, some of the criteria require subjective judgment, whereas some criteria (such as job experience or completion of military service) require objective assessment. In this real-life case study, two different positions - maritime transportation sales department and road transportation sales department - are evaluated to demonstrate the usage of methodology for different positions. In both cases, real data have been used.

By using the results of this study, some conclusions can be made for both human resource managers and job applicants of logistics sales departments. Criteria weights are determined by the decision-makers of the case study company, and therefore, these weights are affected by the company culture and values. However, as the case study company is one of the leaders in the logistics sector in Turkey, these criteria weights can give adequate representation for the rest of the logistics sector in Turkey. The main criteria weights for both maritime and road sales departments remain unchanged, but the sub-criteria weights differ for maritime and road sales positions. The interpretation of the same main criteria weights for both maritime and road transportation is that the basic requirements and expectations of sales personnel are the same for both positions. The main reasons for the difference in the sub-criteria weights are the differences in the qualifications in both positions due to the nature of the transportation modes and the differences in the customer profile and expectations. Maritime transportation sales employees interact with foreign customers, whereas road transportation sales employees mainly interact with local customers. Therefore, these two different customer profiles require different levels of qualifications. This difference is also important in customer expectations and available communication channels. Thus, our study shows that the proposed methodology can flexibly handle the different requirements in various positions and help to select the best candidate for a job.

In this study, criteria weights and the best candidate for the sales position are determined by using the AHP method. However, the number of pairwise comparisons increases as the number of candidates increases. This can create some difficulties and inconsistencies during the pairwise comparisons. To overcome this problem, the best candidate can be determined using different multi-criteria decisionmaking methods (e.g., TOPSIS or ELECTRE). Our study only considers the hiring process for the sales department. As another extension, different job positions can be tested using our methodology. Lastly, our study can be applied to other logistics companies to see the differences between the required qualifications of sales departments. 